\title{
Lapurdum
}

Euskal ikerketen aldizkaria | Revue d'études basques |

Revista de estudios vascos | Basque studies review

Numéro spécial 2 | 2015

Othoi çato etchera

\section{Maria de Lamarq-en gutuna}

\section{Xabier Lamikiz}

\section{OpenEdition}

Journals

Édition électronique

URL : https://journals.openedition.org/lapurdum/2571

DOI : 10.4000/lapurdum.2571

ISSN : 1965-0655

\section{Éditeur}

IKER

\section{Édition imprimée}

Date de publication : 1 octobre 2015

Pagination : 210-211

ISBN : 978-2-9553413-1-5

ISSN : $1273-3830$

\section{Référence électronique}

Xabier Lamikiz, «3. Maria de Lamarq-en gutuna», Lapurdum [Linean], Numéro spécial 2 | 2015, Sarean emana----an 01 septembre 2016, kontsultatu 01 avril 2023. URL: http://journals.openedition.org/ lapurdum/2571 ; DOI: https://doi.org/10.4000/lapurdum.2571

\section{(2) $(0 \Theta \Theta$}

Creative Commons - Attribution-NonCommercial-NoDerivatives 4.0 International - CC BY-NC-ND 4.0

https://creativecommons.org/licenses/by-nc-nd/4.0/ 


\title{
Le Dauphin dokumentazioaren argazki zenbait
}

\author{
1. Rôle d'équipage
}

2. Joanes de Matet-en gutuna

3. Maria de Lamarq-en gutuna

4. Mari Darbururen gutuna

5. Francha Barrereren gutuna 


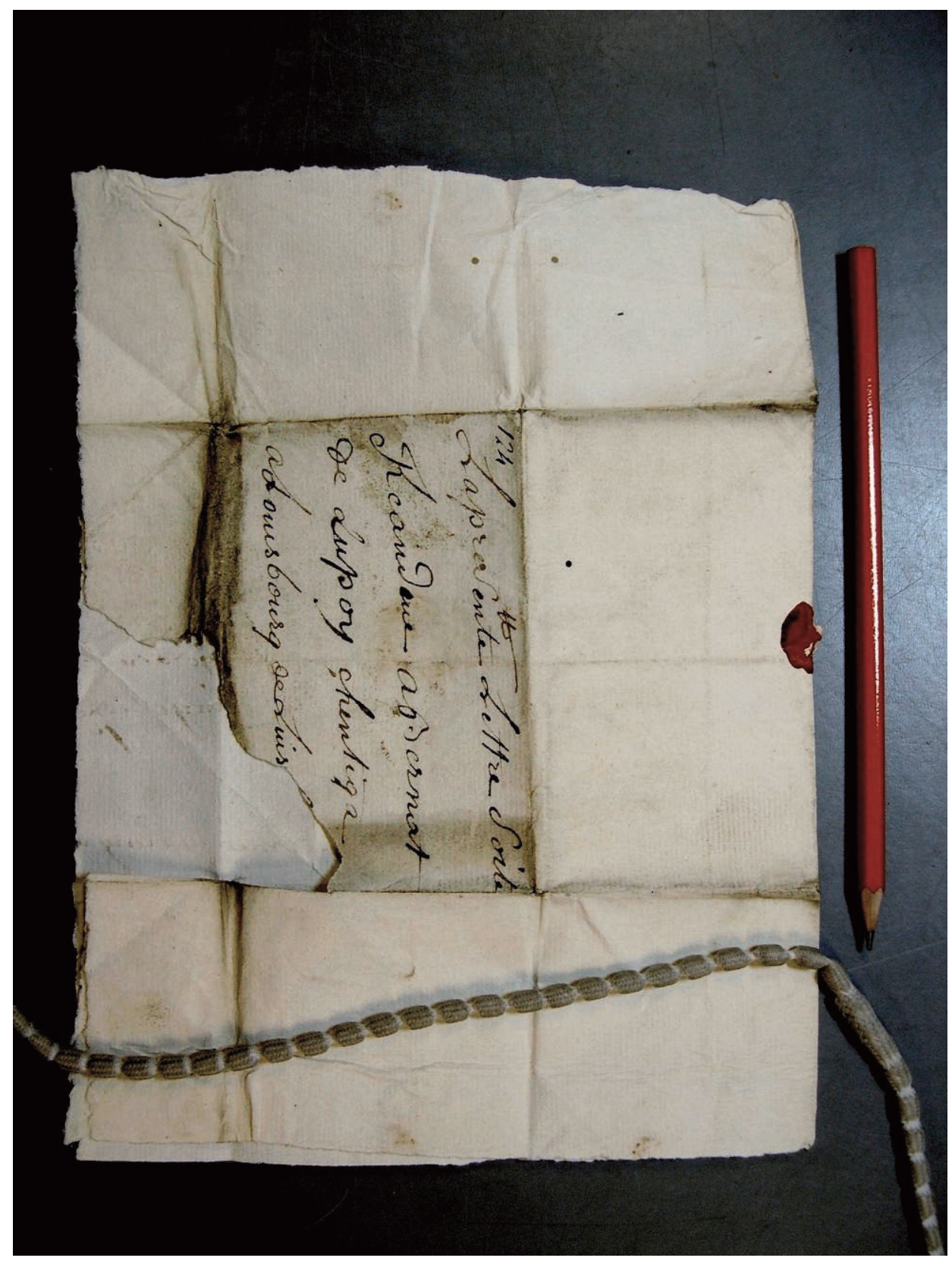

3. Maria de Lamarq-en gutuna, edizio honetako 18.a (TNA, HCA 30/264). Argazkia: Xabier LAMIKIZ. 


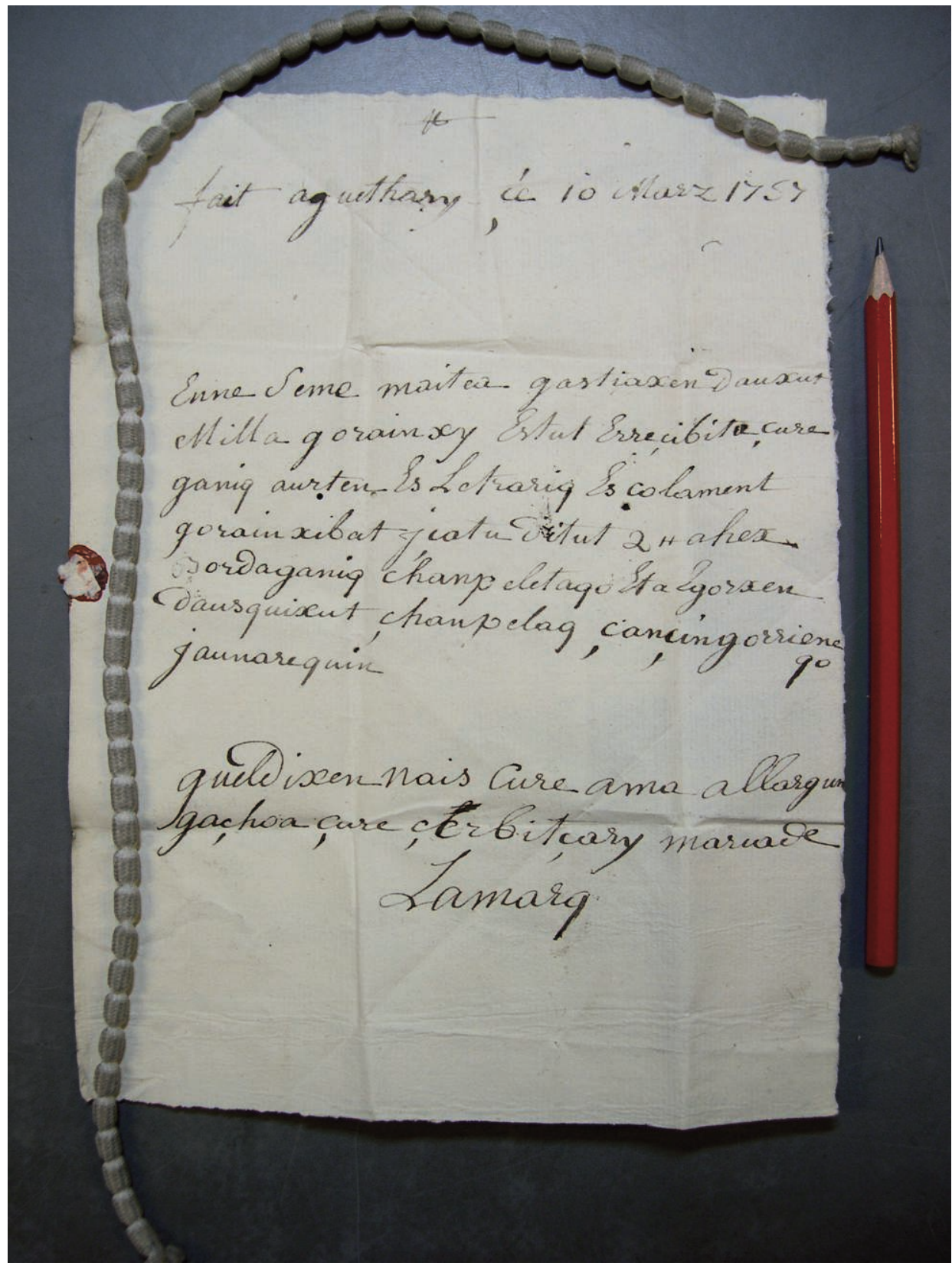

3. Maria de Lamarq-en gutuna, edizio honetako 18.a (TNA, HCA 30/264). Argazkia: Xabier LAMIKIZ. 